\title{
PENGUATAN SENI PERTUNJUKAN JATHILAN ANAK DI KAMPUNG WISATA KADIPATEN KECAMATAN KRATON DIY
}

\author{
Christina Rochayanti ${ }^{1}$, Ida Wiendijarti ${ }^{2}$, Rosalia Indriyati Saptatiningsih ${ }^{3}$ \\ ${ }^{1}$ Universitas Pembangunan Nasional "Veteran" Yogyakarta \\ ${ }_{2}^{2}$ Universitas Pembangunan Nasional "Veteran" Yogyakarta \\ ${ }^{3}$ Universitas PGRI Yogyakarta \\ Email: 1christina.rochayanti@upnyk.ac.id; 2idawiendijarti@yahoo.co.id
}

\begin{abstract}
Abstrak: Tari jatilan yang berada di Yogyakarta sudah cukup dikenal masyarakat, kelompok seni tari ini dapat mengalihkan anak-anak tidak bermain handphone sekaligus mengenalkan seni budaya lokal. Kegiatan pengabdian kepada masyarakat ini bertujuan untuk penguatan kelompok seni tari anak-anak dalam mengenalkan dan melestarikan seni budaya lokal. Kegiatan ini dilaksanakan di Kampung Wisata Kadipaten Kecamatan Kraton DIY. Metode yang digunakan dalam kegiatan ini yaitu dengan membentuk kelompok tari yang terdiri dari anak-anak usia 10 - 15 tahun, melatih mereka dengan gerakan tarian jatilan selama satu bulan, kegiatan ini juga melibatkan pelatih tari yang mengetahui karakter anak-anak agar bersedia menari klasik dan kemudian di pentaskan, didokumentasikan untuk didaftarkan sebagai Hak Kekayaan Intelektual. Kesenian tari Jathilan dipilih oleh kampung wisata Kadipaten sebagai salah satu daya tarik bagi wisatawan yang berkunjung. Pentas kesenian Jathilan , diharapkan bisa menginspirasi anak-anak muda lainnya untuk turut melestarikan seni budaya tradisional, sehingga diharapkan dengan memperbanyak kegiatan yang bersentuhan dengan budaya lokal, anak-anak muda dapat lebih mencintai dan turut berpartisipasi dalam melestarikan dan mewariskan budaya.
\end{abstract}

Kata kunci: Tari Jathilan, kampung wisata, dan penguatan kelompok seni.

\begin{abstract}
Jatilan dance in Yogyakarta is well known to the public, this dance group can divert children from playing mobile phones while introducing local cultural arts. This community service activity aims to strengthen children's dance groups in introducing and preserving local cultural arts. This activity was carried out in Kadipaten Tourism Village, Kraton District, DIY. The method used in this activity is by forming a dance group consisting of children aged $10-15$ years, training them with jatilan dance movements for one month, this activity also involves a dance trainer who knows the character of children to be willing to dance classically and then performed, documented for registration as Intellectual Property Rights. Jathilan dance was chosen by the Kadipaten tourist village as one of the attractions for tourists visiting. Jathilan art performances are expected to inspire other young people to help preserve traditional arts and culture, so that it is hoped that by increasing activities that are in contact with local culture, young people can love and participate more in preserving and passing down culture.
\end{abstract}

Keywords: Jathilan dance, tourist village, and strengthening of art groups.

\section{PENDAHULUAN}

Kesenian Jathilan merupakan salah satu jenis kesenian tradisional yang ada di wilayah Daerah Istimewa Yogyakarta (DIY). Sebagai warisan budaya lokal, kesenian jatilan menjadi bagian tak terpisahkan dari masyarakat pendukungnya. Kesenian Jathilan sebagai produk budaya merupakan hasil interaksi antara masyarakat lokal dan lingkungan sekitarnya, yang di dalamnya memuat ideide, gagasan, pemikiran yang menjadi dasar bertindak dalam hidup bersama. Dampak dari interaksi antar-individu tersebut maka terbentuk sistem nilai, pola pikir, sikap, perilaku kelompok- kelompok sosial, kebudayaan, lembaga, dan lapisan atau stratifikasi sosial (Soekamto, 2003). Dalam penampilannya kesenian Jathilan menggunakan properti kuda képang. Pertunjukan Jathilan ditampilkan dengan mengambil cerita roman Panji, namun dalam perkembangannya, kini Jathilan tidak hanya bertumpu pada cerita roman Panji, tetapi dapat pula mengambil setting cerita wayang (Mahabarata atau Ramayana) dan legenda rakyat setempat (Kuswarsantyo, 2013)

Kampung wisata Kadipaten berada di dalam beteng Kraton Yogyakarta. Kondisi dan situasinya sangat tenang meskipun di dalam kota namun masyarakatnya sangat guyup atau rukun dalam 
melakukan akitifitas sosial. Aspek sosial yang mendukung kegiatan kesenian adalah keterlibatan warga, hal ini menunjukkan adanya dukungan sosial yang bisa menjadi potensi. Pengelola kampung wisata berusaha untuk melaksanakan kegiatan seni sebagai bentuk sosialisasi antarwarga sekaligus untuk melestarikan budaya lokal yang mulai ditinggalkan. Hal ini tentu sebagai upaya untuk meningkatkan minat berkesenian dikalangan masyarakat sekaligus sebagai upaya untuk menjaga warisan seni dan budaya agar tidak punah. Upaya untuk menjaga pelestarian seni tradisional tentu tidak dapat dilakukan secara sepihak saja dengan hanya menyajikan kepada masyarakat namun perlu untuk melibatkan secara aktif seluruh elemen masyarakat baik dari anak-anak sampai pemerintah, akademisi serta berbagai pihak.

Permasalahan saat ini anak-anak kurang mendapatkan ruang untuk terlibat dalam kesenian karena tarian yang dilakukan bisanya tarian untuk orang dewasa, belum banyak tarian untuk anakanak yang kemudian bisa ditempilkan dalam gelar budaya ini. Hal ini menjadikan anak-anak hanya sebgai penonton saja, apabila sejak kecil mereka tidak dilibatkan maka semakin lama kesenian tradisional akan punah karena tidak ada regenerasi bagi para pelakunya. Keterlibatan anak-anak untuk mau berkesenian baik itu untuk memainkan gamelan atau alat kesenian lainnya, serta untuk ikut melakukan seni tari bukanlah suatu yang mudah, mengingat saat ini kegiatan sekolah yang padat serta hadirnya teknologi modern yang lebih mampu memberikan hiburan bagi mereka secara instan. Untuk itu perlu upaya serius untuk mengemas seni tari dengan memasukkan unsurunsur modern supaya bisa membuat anak-anak lebih bersemangat. Hal ini menjadi tantangan bagi pengelola kampung wisata untuk melibatkan anakanak dan memberikan ruang bagi mereka untuk melaksanakan kegiatan sesuai dengan porsinya. Hal ini tentu memerlukan sarana dan prasarana yang mampu menampung dan mengarahkan minat mereka supaya mampu menjadikan anak-anak sebagai generasi penerus bagi pelestarian nilai-nilai budaya.

Pelembagaan kesenian Jathilan merupakan upaya untuk memasukkan unsur-unsur modern tanpa menghilangkan nilai-nilai yang ada, adalah dengan melakukan penyesuaian sistematika urutan gerakan yang dianggap mudah untuk ditarikan oleh anak-anak serta sebagai bentuk edukasi mengenai pentingnya melestarikan seni budaya lokal. Modernisasi menuntut hidup yang lugas (zakelijk), rasional, dan memandang jauh ke depan dalam perkembangan (Kayam, 1999). Demikian pula dalam upaya melestarikan seni tradisional, perkembangan teknologi telah mempengaruhi gaya hidup dan perilaku masyarakat, maka untuk mengantisipasi tergerusnya kesenian tradisional budaya lokal, maka kami berupaya melakukan pengabdian kepada melalui pelembagaan seni pertunjukan dan mengambil sasaran anak-anak sebagai pelaku kesenian tari Jathilan, dengan harapan anak-anak sebagai generasi penerus membutuhkan media pengetahuan dan pelatihan sebagai upaya pelestarian budaya.

Revitalisasi pertunjukan kesenian Jathilan merupakan salah satu bagian dari usaha konservasi seni tradisi. Konsep konservasi mencakup empat komponen utama, yaitu preservasi, restorasi/rehabilitasi, rekonstruksi, dan revitalisasi (Puspari, 1997). Revitalisasi adalah usaha merubah suatu jenis seni tradisi yang disesuaikan dengan perkembangan masyarakat dan memiliki fungsi baru tanpa menghilangkan roh kesenian itu (Komala, 2003). Revitalisasi seni jatilan dimaksudkan untuk menggali dan memberi makna baru terhadap kesenian itu tanpa harus merubah substansi dan bentuknya. Bila kesenian itu dahulu berfungsi magis ataupun sebagai hiburan dalam penyelenggaraan acara adat masyarakat setempat, maka dalam konteks kekinian fungsi itu perlu disesuaikan dengan perubahan zaman, misalnya, dijadikan atraksi wisata budaya. Bahkan para pelaku wisata seperti biro perjalanan dalam mengemas kesenian tradisional termasuk jathilan untuk konsumsi wisatawan, adalah bukti nyata bahwa kesenian tradisional kini telah menjadi bagian dari komersialisasi budaya yang disebut pariwisata (Yoety, 1993). Oleh karena itu, kegiatan pengabdian ini juga akan menjadikan potensi kesenian tradisional Jathilan bagi penguatan identitas daerah dan pengembangan pariwisata di Kampung Wisata Kadipaten serta mengupayakan pelaku pariwisata di Kampung wisata Kadipaten dalam merevitalisasi potensi kesenian tradisional Jathilan bagi perkembangan dunia wisata.

\section{METODE}

Kegiatan pengabdian pada masyarakat kampung Kadipaten bertujuan untuk meningkatkan potensi wisata yang ada di Kampung Wisata Kadipaten Kecamatan Kraton Yogyakarta, melalui pelembagaan kesenian Jathilan, khususnya di kalangan anak-anak, yang dilakukan melalui: observasi, dan pelatiham sebagai berikut:

a) Membuat kreasi tema cerita dan gerakan pada seni tari Jathilan dengan memasukkan unsurunsur gerakan modern serta menanamkan nilainilai bela negara melalui variasi gerakangerakan tari dengan tema cerita 'Raden Ronggo".

b) Memilih anak-anak dan remaja usia 12-25 tahun untuk memerankan tokoh dan pendukung tari dengan tema cerita "Raden Ronggo"

c) Melakukan latihan intensif untuk mengkolaborasikan gerakan-gerakan tari antar penaru, 
supaya mampu dilakukan dengan baik sesuai dengan tema cerita

d) Melakukan pendampingan selama proses latihan baik pada penataan tarian, penyesuaian kostum dan iringan gamelan untuk mendukung pementasan.

e) Memfasilitasi pementasan seni tari Jathilan dengan tema cerita "Raden Ronggo" pada kegiatan gelar budaya yang diselenggarakan oleh warga Kampung Wisata Kadipaten, Kecamatan Kraton Yogyakarta.

\section{HASIL KEGIATAN DAN PEMBAHASAN}

\section{Sekilas Kampung Wisata Kadipaten Keca- matan Kraton Yogyakarta}

Secara administratif Kampung Wisata Kadipaten "Art and heritage Tourism", berada di wilayah Kecamatan Kraton Yogyakarta. Sebagaimana diketahui, bahwa Kraton Yogyakarta adalah merupakan salah satu tujuan utama di Yogyakarta, karena Kraton merupakan pusat apresiasi seni dan budaya yang di dalamnya terdapat potensi obyek dan tujuan wisata unggulan, seperti : heritage, atraksi seni dan budaya kraton, kuliner dan cinderamata khas Yogyakarta. Semua potensi tersebut telah terbukti mampu memberikan daya tarik dan pengalaman yang cukup unik dan khas bagi wisatawan yang telah maupun yang akan berkunjung di Yogykarta. Pengelola kampung wisata Kadipaten, nampaknya memiliki beberapa paket wisata yang bisa dipilih oleh para wisatawan sesuai dengan minat dan tujuan wisatanya. Beberapa paket wisata tersebut antara lain, dinner at heritage, kesenian tradisional 'Gejog Lesung', Jelajah situs, Lansianos, kursus tari dan karawitan serta wisata kuliner kraton.

\section{Realisasi kegiatan Pengabdian}

\section{Tahap pertama}

Pelaksanaan kegiatan pelembagaan kesenian tari Jathilan di Kampung Wisata Kadipaten di wikayah Kecamatan Kraton Yogyakarta, dimulai dari diskusi kami selaku tim pengabdian dengan bapak Kuswarsantyo selaku penata tari dan pengelola Kampung Wisata Kadipaten, untuk menentukan tema cerita yang sesuai dengan jiwa anak-anak serta dengan memasukkan nilai-nilai bela negara yang disesuaikan dengan unsur-unsur modern saat ini. Tema cerita Raden Ronggo dipilih karena mengisahkan seorang pangeran yang sedang menghadapi masalah, yaitu adanya musuhmusuh jahat yang mengincar kedudukan pangeran. Adanya musuh-musuh yang mengancam pangeran tersebut, maka dengan dibantu para prajuritprajurit berkuda, maka musuh-musuh yang berniat jahat tersebut mampu dikalahkan.
Tema cerita Raden Ronggo putra dari Panembahan Senopati yang terlahir dengan kesaktian. Pada suatu hari ketika Raden Ronggo dan prajuritnya akan melaksanakan tugas, dihadang tiga raksasa, namun berkat kesaktiannya ketiga raksasa berhasil ditaklukkan. Untuk itu penting bagi anak-anak untuk diberikan bekal penanaman nilainilai bela negara melalui berbagai cara, salah satunya melalui kesenian tari sebagai upaya untuk memberikan ketahanan dan ketangguhan bagi fisik dan psikis anak-anak untuk mencintai nilai-nilai budaya lokal supaya tidak punah, karena punahnya budaya tradisional berarti hilangnya sebagian dari nilai-nilai berbangsa dan bernegara, sehingga bisa berakibat masuknya nilai-nilai asing yang tidak sesuai dengan adat dan budaya bangsa Indonesia.

\section{Tahap kedua}

Langkah selanjutnya setelah menentukan tema cerita dan mengelola gerakan tari jathilan adalah menentukan pemeran dari tokoh-tokoh pendukung sesuai dengan anak-anak dan remaja yang terlibat dalam kesenian tari Jathilan. Berdasarkan dari hasil pemilihan ditentukan 1 orang berperan sebagai Raden Ronggo (tokoh utama), 3 orang sebagai buto (tokoh jahat/musuh) dan 6 orang anak sebagai prajurit berkuda. Setelah menentukan pemeran, maka masing-masing pemain diberikan gambaran mengenai tema cerita dan variasi gerakan-gerakan tari yang akan dilakukan.

\section{Tahap ketiga}

Setelah para pemain mendapatkan pemahaman mengenai jalan cerita dan gerakan tari, maka selanjutnya adalah melatih secara intensif masingmasing gerakan pada para pemain, untuk bisa melakukan gerakan tari yang benar dan terarah. Para pelatih mengamati satu persatu pemain dalam melakukan gerakan tari dan mengajarkan gerakangerakan yang benar dan tepat, untuk itu para pemain juga diminta untuk menghayati setiap gerakan supaya para pemain bisa menghidupkan tokoh yang diperankan. Untuk bisa melakukan gerakan tari yang benar dan menghayati, para pemain memerlukan latihan secar intensi selama beberapa kali latihan, yang dilakukan seminggu dua kali selama 2-3 jam,pada sore hari setelah anak-anak pulang sekolah.

Setelah gerakan tari pada masing-masing pemain dianggap sudah benar dan cukup menghayati, latihan berikutnya adalah menggabungkan gerakan tari pada masing-masing penari, dengan penari yang lain sesuai denganjalan cerita yang sudah disusun sebelumnya. Sistematika gerakan tari menjadi unsur penting dalam kegiatan ini, mengingat pelembagaan unsur gerakan tari yang tersistematis inilah yang kemudian akan dijadikan sebagai hak kekayaan intelektual, sebagai upaya pelestarian seni tradisional. 


\section{Tahap keempat}

Tim pengabdian melakukan pendampingan selama latihan, untuk melakukan observasi dan dokumentasi terhadap kegiatan latihan. Beradasarkan hasil observasi diketahui bahwa anak-anak yang ikut terlibat dalam kegiatan seni tersebut, nampaknya memiliki perilaku yang santun dalam bertutur kata dan berperilaku dengan teman dan sopan terhadap orangtua. Hal ini merupakan dampak positif yang akan membekali mereka dalam berkegiatan di masyarakat, karena mereka secara tidak langsung menerapkan nilai-nilai tradisional dalam berkesenian tersebut dalam perilakunya sehari-hari.

Melalui berkesenian, nampaknya selain mampu untu mengisi kegiatan mereka di waktu luang juga mampu memberikan bekal kepada anak-anak mengenai nilai-nilai dalam budaya tradisional, supaya mereka tahu dan memahami akan nilainilai tersebut dan tertanam dalam benak mereka, sehingga nilai-nilai tersebut secara langsung maupun tidak langsung menjadi pedoman dalam perilakunya. Hal ini terlihat dari bagaimana mereka ketika menggabungkan gerakan tari dengan penari yang lain, sesuai dengan peran masingmasing sesuai dengan jalan cerita dan tabuhan yang mengiringi.

Proses menciptakan tabuhan sesuai dengan gerakan tari dan tema cerita merupakan hal yang tidak mudah, para penabuh harus mencermati setiap gerakan supaya menjadi satu kolaborasi yang indah antara gerakan tari dan tabuhan. Untuk itu diperlukan kesungguhan dari masing-masing penari yang terlibat untuk saling menyesuaikan dengan iringan penabuh.

\section{Tahap kelima}

Tahap terakhir adalah memfasilitasi kegiatan pementasan seni tari Jathilan dengan tema cerita Raden Ronggo. Pementasan kesenian Jathilan dipentaskan pada kegiatan Gelar Potensi Wilayah Budaya yang diselenggarakan oleh Paguyuban Kesenian, Kecamatan Kraton dengan didukung oleh Dinas Pariwisatan Daerah Istimewa Yogyakarta, pada tanggal 9 Agustus 2019 di Ndalem Benawa. Tarian dibuka dengan munculnya 6 orang prajurit berkuda yang melakukan berbagai gerakan dinamis dengan membawa kuda, yang menunjukkan semangat mereka dalam menjaga keamanan. Kemudian ditengah-tengah gerakan prajurit, muncul tokoh utama, yaitu Raden Ronggo, yang berbalut kostum putih, yang dengan gerakan menawan, menunjukkan kewibawaan dan kesaktiannya, melalui gerakan yang berbaur dengan prajurit berkuda.

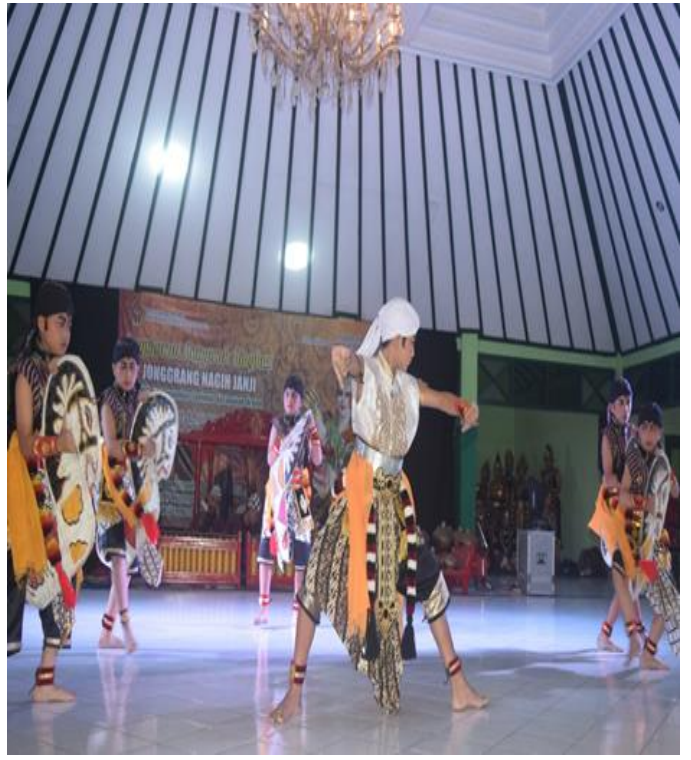

Gambar 1. Pementasan ketika adegan Raden Ronggo menunjukkan kesaktian

Setelah itu, panggung digantikan dengan munculnya 3 orang musuh yang digambarkan dengan karakter 'raksasa' dengan kostum dominan merah dengan rambut gimbal yang kemudian bertarung dengan prajurit berkuda, namun nampaknya kekuatan prajurit berkuda tidak mamp mengalahkan musuh, sehingga datangnya Raden Ronggo dengan kesaktiannya mampu mengalahkan musuh.

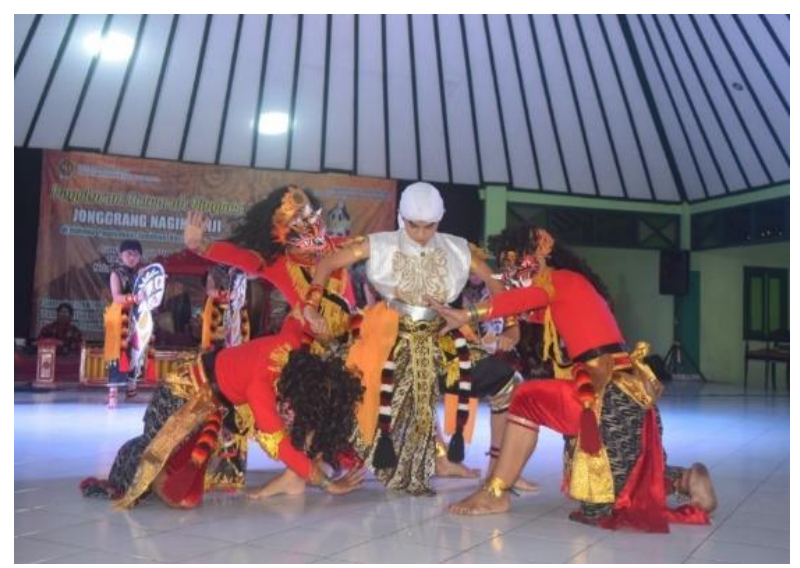

Gambar 2. Pementasan ketika adengan Raden Ronggo di serang buto

Inti dari cerita Raden Ronggo melalui tari Jathilan adalah untuk menggambarkan bahwa halhal yang negatif yang bertujuan jahat, pasti bisa dikalahkan dengan semangat kebersamaan dan penuh perjuangan. Inilah nilai-nilai bela negara yang diharapkan mampu dihayati oleh para penari maupun penonton, artinya melalui kesenian tradisional Jathilan kita bisa menyisipkan penanaman nilai-nilai bela negara untuk memberikan bekal ketahanan bela negara, khususnya bagi generasi muda. 


\section{PEMBAHASAN}

Kampung Wisata Kadipaten "Art and heritage Tourism", yang berada di wilayah Kecamatan Kraton Yogyakarta, merupakan potensi besar yang sangat menguntungkan, karena wilayah Kraton Yogyakarta merupakan salah satu tujuan utama wisatawan dalam berkunjung ke Yogyakarta Selain itu Kraton merupakan pusat apresiasi seni dan budaya yang di dalamnya terdapat potensi obyek dan tujuan wisata unggulan, seperti: heritage, atraksi seni dan budaya kraton, kuliner dan cinderamata khas Yogyakarta. Hal ini merupakan potensi unggulan yang wajib untuk dipertahankan dan dilestarikan. Memadukan antara seni budaya dan aspek ekonomi merupakan paduan yang saling melengkapi dalam upaya meningkatkan kesejahteraan masyarakat. Untuk itu perlu upaya saling bekerja sama berbagai pihak terkait untuk, saling mendukung, supaya seni dan budaya tidak punah namun bisa mendukung sektor ekonomi.

Agar kesenian Jathilan dapat dijadikan ikon (daya tarik) pariwisata di kampung wisata Kadipaten, Kecamatan Kraton Yogyakarta, memang membutuhkan keterlibatan dari seluruh komponen masyarakat, seperti seniman, pemerintah, pelaku pariwisata, dan akademisi untuk mengembangkannya. Sebenarnya pemerintah Propinsi Daerah Istimewa Yogyakarta melalui Dinas Kebudayaan dan Pariwisata telah merancang satu strategi bagi pengembangan kesenian di wilayah Propinsi Daerah Istimewa Yogyakarta dengan menggelar beragam potensi budaya yang ada di tiap wilayah, baik ditingkat kecamatan maupun kabupaten, sebagai identitas kesenian khas daerah.

Berbagai upaya sudah dilaksanakan untuk mendukung seni dan budaya berkembang di Daerah Istimewa Yogyakarta dengan :

a. Meningkatkan wawasan, kreativitas penampilan (pemakaian atribut seperti kuda kepang, gending, dan musik) para seniman Jathilan melalui acara sarasehan.

b. Pemerintah daerah menfasilitasi pagelaran dan festival kesenian Jathilan, seperti pada acara peringatan hari besar nasional .

c. Dinas Kebudayaan dan Pariwisata Kabupaten DIY memotivasi dan memberi fasilitas bagi seniman yang ingin berlatih meningkatkan keterampilannya.

d. Mempermudah pengurusan ijin tontonan bagi masyarakat yang akan mementaskan kesenian Jathilan

e. Menjadikan kesenian Jathilan sebagai kesenian khas Yogyakarta, sehingga setiap ada acara festival kesenian rakyat, baik di tingkat propinsi maupun nasional., seni tari Jathilan menjadi unggulan.

Usaha merevitalisasi kesenian Jathilan sebagai penguatan identitas daerah melalui pengembangan pariwisata antara lain dapat dilakukan melalui langkah-langkah strategis berikut: (1) melakukan pengemasan kesenian Jathilan sebagai atraksi budaya Kampung wisata Kadipaten Kecamatan Kraton dengan mengedepankan nilai-nilai kearifan lokal yang terkandung di dalamnya, (2) menyediakan alternatif atraksi wisata di berbagai obyek dan daya tarik wisata di Kampung wisata Kadipaten Kecamatan Kraton, (3) meningkatkan kualitas penampilan dan pementasan kesenian Jathilan melalui berbagai institusi pendidikan seni baik formal maupun non-formal, (4) mengembangkan wisata minat khusus berbasis atraksi kesenian Jathilan, (5) memelihara dan mengembangkan berbagai ragam penampilan Jathilan yang berkembang di masyarakat, serta menghindari usahausaha penyeragaman yang tidak produktif dan mematikan kreatifitas, (6) melakukan pengelolaan gedung kesenian sebagai pusat pengembangan kesenian Jathilan, (7) memanfaatkan media masa baik elektronik maupun cetak serta media sosial melalui upaya pengelolaan website tentang kesenian Jathilan dengan segenap komponen pementasan dan latar belakang sejarahnya sebagai media pemasaran yang efektif, (8) melaksankan promosi melalui pergelaran seni pertunjukan tradisional di pusat-pusat seni dan budaya di kota-kota, daerah serta negara yang merupakan sumber wisatawan, dan (10) menyelenggarakan event pariwisata dengan melibatkan kesenian Jathilan secara terintegrasi.

Dengan semakin kuatnya kelompok kesenian Jathilan, maka akan meningkatkan nilai tambah bagi kamung wisata Kadipaten Kecamatan Kraton, dengan identitasnya, sehingga masyarakat akan terlibat secara aktif dalam melestarikan dan mengembangkannya. Untuk itu perlu adanya kepedulian untuk tetap memberikan dukungan baik berupa sarana dan prasarana serta dukungan moril untuk kelangsungan kesenian Jathilan ini, khususnya dikalangan generasi muda, sebagai generasi penerus.

Kegiatan berkesenian bisa menjadi alternatif kegiatan yang bisa digunakan oleh anak-anak dan remaja untuk mengisi waktu di luar kegiatan belajar di sekolah. Anak-anak dan remaja juga bisa mengasah jiwa seni dan kreatifitasnya dengan berkreasi melalui gerakan-gerakan tari lainnya, tanpa meninggalkan nilai-nilai budaya lokal serta mampu berpartisipasi dalam menjaga dan melestarikan seni dan budaya bangsa.

\section{KESIMPULAN}

Berdasarkan hasil pembentukan kelompok tari dan pendampingan dapat diperoleh beberapa hal terkait dengan kesinambungan kegiatan latihan sebagai daya tarik bagi kampung wisata Kadipaten Kecamatan Kraton antara lain bahwa adanya dukungan dari masyarakat sekitar memberikan kontribusi yang besar terutama dengan memberi 
kesempatan pada anak-anak dan remaja untuk mengikuti latihan tari dan mengembangkan seni Jathilan di wilayahnya.

Adanya kelompok seni dan latihan tari secara berkesinambungan telah memberikan ruang bagi generasi muda untuk turut melestarikan budaya tradisional.

Untuk menjadikan kesenian Jathilan sebagai penguat identitas daerah serta daya tarik wisata masih membutuhkan upaya pemberdayaan dan peran serta stakeholder di bidang pariwisata. Dunia pariwisata adalah dunia kemasan, sehingga para seniman Jathilan harus sadar bahwa apabila keseniannya ingin diakses dalam dunia wisata, maka mereka harus mengemas dengan baik, sehingga benar-benar dapat menjadi tontonan yang menghibur. Itulah sebabnya unsur entertainment dan manajemen pertunjukan perlu diberikan kepada para senimannya, di samping sikap-sikap profesional dan kreativitas.

Pelaksanaan Gelar budaya oleh pemerintah kota DIY,sebagai upaya meningkatkan wawasan, kreativitas penampilan para seniman serta memotivasi dan memberi fasilitas bagi seniman yang ingin meningkatkan keterampilannya merupakan usaha pemberdayaan kesenian ini sebagai asset pariwisata. Jika semua usaha pemberdayaan ini terlaksana bukan tidak mungkin akan terjadi perubahan kehidupan bagi para seniman Jathilan yang semakin baik (datangnya keuntungan bersifat materi), diperolehnya pemasukan (devisa) bagi pemerintah (daerah dan pusat), serta akan mendorong semakin suburnya kesenian tradisional rakyat yang lain. sebagai penguat identitas daerah serta daya tarik wisata masih membutuhkan upaya pemberdayaan dan peran serta stakeholder di bidang pariwisata.

Apabila semua usaha pemberdayaan ini terlaksana, bukan tidak mungkin akan terjadi perubahan kehidupan bagi para seniman yang semakin baik (datangnya keuntungan bersifat materi), diperolehnya pemasukan (devisa) bagi pemerintah (daerah dan pusat), serta akan mendorong semakin suburnya kesenian tradisional rakyat yang lain.

Rekomendasi yang ditawarkan, apabila kesenian tari Jathilan dipilih oleh kampung wisata Kadipaten sebagai salah satu daya tarik bagi wisatawan, maka perlu pengelolaan yang baik dengan memilih dan menentukan pengelola dari anggota masyarakat yang memiliki kepedulian terhadap kesenian dan pariwisata, untuk menjadi pengurus yang mana kepengurusan tersebut tertata dalam struktur organisasi yang bisa dilegalkan, sehingga setiap kegiatan dapat terencana dan dilaksanakan serta dilakukan evaluasi, karena setiap kegiatan memiliki penanggungjawab masingmasing. Salah satu kegiatannya adalah pentas kesenian Jathilan yang bisa direncanakan secara rutin pada event-event budaya, sehingga diharapkan bisa menginspirasi anak-anak muda untuk turut melestarikan seni budaya tradisional,

\section{DAFTAR PUSTAKA}

Kayam, U. ( 1999). Seni Pertunjukkan dan Sistem Kekuasaan. Jurnal Seni Volume 2 Nomor 1, Okbtober, 7-15.

Komala, L. (2003). Peranan Nilai-Nilai Tradisional dalam Kehidupan Modern \& Integritas bangsa (naskah pidato). Surakarta: Forum Komunikasi dan Informasi Keraton \& Bappenas.

Kuswarsantyo. (2013). Seni Jathilan: Bentuk, Fungsi dan Perkembangannya (1986-2013). Yogyakarta: Fakultas Bahasa dan Seni UNY.

Puspari. (1997). Penelitian Pengembangan Kesenian Tradisional. Jakarta: Proyek Penelitian dan Pengembangan Bidang Budaya \& Pariwisata kementrian Kebudayaan dan Pariwisata RI.

Soekamto, S. (2003). Sosiologi. Jakarta: PT. Raja Grafindo Persada.

Yoety, O. A. (1993). Komersialisasi Seni Budaya Dalam Pariwisata. Bandung: Bintang Angkasa. 